\title{
Groundwater Pumping Management in Controlling Seawater Up-Coning in The North Coastal Area of Makassar
}

\author{
Sugiarto Badaruddin ${ }^{1, \mathrm{a}}$, Akhmad Azis ${ }^{1, \mathrm{~b}}$, Muhammad Fadhil Ashari ${ }^{1, \mathrm{c}}$, Miftahul Jannah ${ }^{1, \mathrm{~d}}$, Ilham Ali ${ }^{2, \mathrm{e}}$, and \\ Muhammad Ihsan ${ }^{3, f}$ \\ ${ }^{1}$ Civil Engineering Department, State Polytechnic of Ujung Pandang, P.O. Box 90245, South Sulawesi, Indonesia \\ ${ }^{2}$ Dinas Pengelolaan Sumber Daya Air Kabupaten Bone, South Sulawesi, Indonesia \\ ${ }^{3}$ Civil Engineering Department, Sekolah Tinggi Teknik Baramuli, Pinrang, Souh Sulawesi, Indonesia \\ ${ }^{\text {a }}$ sugibadaruddin@poliupg.ac.id \\ bakhmad_azis@yahoo.com \\ cfadhil.sii03@gmail.com \\ dmiftahuljannah320@gmail.com \\ eilhamali2502@gmail.com \\ fmuhammadihsan@alumni.ait.asia
}

\begin{abstract}
In big cities, communities generally consume clean water from local water supply company which uses surface water sources. However, due to the limitations of the company in supplying water, particularly in the dry season, an alternative is required, such as using groundwater without causing overexploitation. This study aims to determine the optimal rate of groundwater pumping in the coastal aquifer to avoid seawater up coning using SEAWAT V.4 numerical model. The research method was carried out using a GEO-7X GPS device to obtain coordinate's location, land elevation and observation well distance from the coastline. Secondary data in the form of aquifer thickness data and geological map of the site were obtained from previous studies. The salinity test results show that the average salinity value of the ten water samples from observation wells is $36.8 \mathrm{mg} / \mathrm{l}$, which means that the water is categorized as non-saline water (freshwater). These data are in line with the groundwater utilization monitoring activity report of Makassar City Environment Office in 2018, which reported that Ujung Tanah and Wajo Districts were found to be free from seawater intrusion. Even so, the potential for seawater intrusion is still considered high because of the location of community groundwater wells are near from the coast. One of the efforts to prevent seawater up coning is by limiting groundwater pumping. From the numerical modeling results, it is found that the maximum groundwater discharge in the research site, namely $\mathrm{P3}$ is $20 \%$ of total flow rate $\left(0.3 \mathrm{~m}^{3} / \mathrm{day}\right)$, $\mathrm{P} 5$ is $20 \%\left(1.32 \mathrm{~m}^{3} / \mathrm{day}\right), \mathrm{P} 6$ is $40 \%\left(0.52 \mathrm{~m}^{3} /\right.$ day $)$ and $P 10$ is $20 \%\left(0.63 \mathrm{~m}^{3} /\right.$ day $)$.
\end{abstract}

Keywords-Seawater Up-coning; Groundwater Pumping; Numerical Modelling

\section{Introduction}

Water is a basic need to support human life. Water is used for daily purposes such as drinking water, irrigation, industry, and others. One source of water is groundwater. In general, groundwater is water that is contained in layers of soil or rocks below the soil surface. Groundwater is formed or flows from the recharge area, immediately when it rains, so it requires a significant amount of time to be in the aquifer layer before finally reappearing naturally at the discharge point, depending on the position of the saturated zone, topography, climatic conditions and aquifer hydraulics [1].

One of the objectives of groundwater management in coastal areas is to maximize groundwater use without causing an invasion of seawater into pump wells. Some management questions can arise regarding this consideration. For existing pump wells, for example, what is the maximum pumping discharge that can be done? For new pump wells, where should the well be located? How to maximize groundwater recharge in coastal aquifers? This question can be answered by using a seawater intrusion simulation model [2]-[4]. 
One of the problems arising from excessive groundwater pumping in coastal aquifers is up-coning. Up-coning is the vertical movement of seawater towards the pump well, and this is a global problem [5]. Previous studies have explained that groundwater pollution due to up-coning will usually cause the pump wells to no longer be used because groundwater quality has been degraded [6]. So far, up-coning seawater has been studied more theoretically because of limited field data about the dynamics of seawater under the pump well.

The most widely used solution regarding up-coning is the solution from [7]. They provide transient solutions for interface movement under pump wells in a coastal aquifer that is unlimited in size. They compared the results obtained from the analytical solution with the results from the sand tank experiments. There is a fairly good fit between the results of the analytical solution and the results of the experiment. [8] was the first to carry out numerical modeling for up-coning under pump wells involving variable-density and the effects of dispersion. They found that the up-coning process was strongly influenced by the dispersion parameters and this result was confirmed by [9] who carried out the same modeling and found that seawater transport was strongly influenced by longitudinal dispersion.

Currently, in the north coastal area of the city of Makassar, the use of groundwater has been very intensive. Because of its location near the coastline, there is a possibility of a significant seawater infiltration in the area. In addition, uncontrolled groundwater uptake in the area can cause a decrease in the groundwater level and cause emptiness in the pores of the soil in the aquifer layer. This decrease in groundwater level causes seawater to move into the aquifer and cause pollution of groundwater.

In this study, numerical modeling is used to determine the condition and description of salinity distribution as a reference parameter for groundwater quality in people's wells around the north coast of Makassar while evaluating the optimal pumping discharge that can be done to control the up-coning around the north shore of the city. Numerical modeling is done by using 2-dimensional models at several observation locations.

\section{Methodology}

\section{A. Conceptual model}

Figure 1 shows a schematic picture of an unconfined coastal aquifer, following the conceptual model used in [10]. Three different salinity contours were measured in evaluating the interface configuration (i.e., 5, 50, and $95 \%$ of seawater salinity), and both the interface toe at the aquifer base $x_{\text {toe }}[\mathrm{L}]$ and the interface tip at the watertable $\mathrm{x}_{\text {tip }}[\mathrm{L}]$ were evaluated. In Figure 1, the right and the left sides represent the coastal and the inland boundaries, respectively, with hs the depth of the horizontal aquifer base below sea level [L], and hf the inland freshwater head [L].

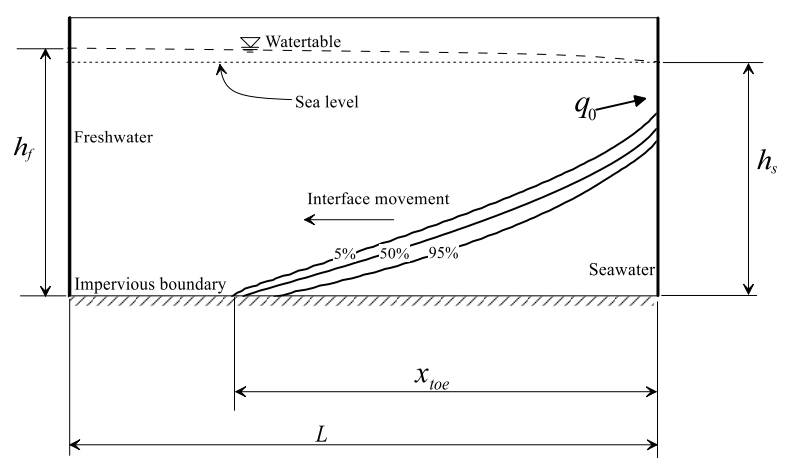

Figure 1. Conceptual model of an unconfined coastal aquifer subjected to SWI and $\mathrm{q}_{0}$ is freshwater discharge to the sea $[\mathrm{L} 2 / \mathrm{T}]$ (adopted from [10]).

\section{B. Research Site and Time Frame}

The location of this research is located on the north coast of Makassar City, namely Ujung Tanah District and Wajo District (See Figure 2). The study was conducted in January 2019 to August 2019.

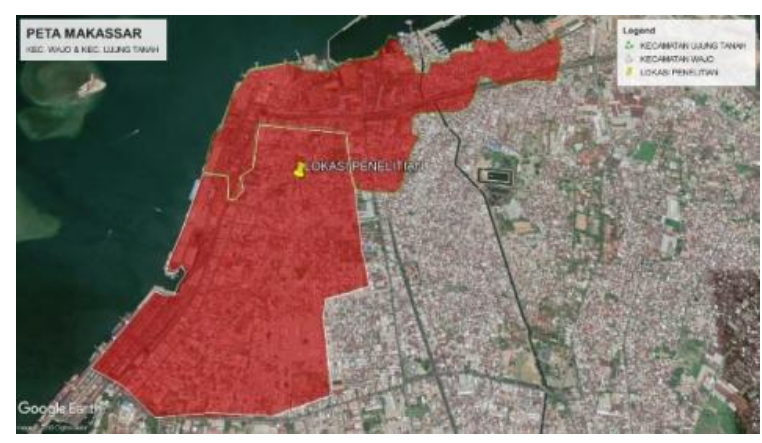

Figure 2. Research site 


\section{Materials}

The tools and materials used in this study are as follows:

1. Conductometer for measuring the salinity of well water samples.

2. GPS Geo $7 \mathrm{X}$ to mark the location point of salinity measurement, measure elevation and distance.

3. $600 \mathrm{ml}$ Sample Bottle for storing water samples.

4. Cooler Box to preserve water samples.

5. Water bucket to take samples from the bucket to the bottle.

6. Roll Meter to measure the height of the top of the well.

7. Water Level to measure the level of water in the well.

8. Stationery for recording measurement and test results.

9. Laptops that have Microsoft Excel, ArcGIS 10.4 and SEAWAT V.4 software installed to process data.

10. Camera to document activities.

11. Aquades for cleaning the conductometer.

The types of data used include primary and secondary data. Primary data include well water salinity data, well coordinates, well water level, distance between wells to shoreline, and well surface elevation. Secondary data includes data obtained from previous studies and related institutions namely aquifer thickness data in the Makassar area collected from the Department of Energy and Mineral Resources of South Sulawesi Province, porosity and soil permeability values obtained from the literature [11] and [12] and other related resources (i.e., [13]).

Data such as soil porosity, soil permeability, well water level, distance between wells to the coastline and other data will be inputted to software called SEAWAT V.4 [14]. These data can be seen in Table 1. Through SEAWAT V.4, numerical modelling will be performed for pumping simulations on each well sample so that it may predict the maximum pumping depth, maximum discharge and the exact pumping location so that there is no up-coning in the future.
Table1. Hydrogeological data used in numerical modelling.

\begin{tabular}{ccccc}
\hline \multirow{2}{*}{ Parameter } & \multicolumn{5}{c}{ Case } \\
\cline { 2 - 5 } & $\mathbf{P 3}$ & $\mathbf{P 5}$ & $\mathbf{P 6}$ & $\mathbf{P 1 0}$ \\
\hline $\mathrm{K}(\mathrm{m} /$ day $)$ & 10 & 10 & 10 & 10 \\
\hline $\mathrm{Z}_{0}(\mathrm{~m})$ & 80 & 200 & 200 & 80 \\
\hline MAT $(\mathrm{m})$ & 2,72 & 2,41 & 1,80 & 2,96 \\
\hline $\mathrm{n}$ & 0,35 & 0,35 & 0,35 & 0,35 \\
\hline$\delta$ & 0,025 & 0,025 & 0,025 & 0,025 \\
\hline $\mathrm{Q}_{\text {tot }}\left(\mathrm{m}^{3} /\right.$ day $)$ & 1,51 & 3,31 & 2,58 & 3,13 \\
\hline
\end{tabular}

Figure 3 is an example of pumping modelling using SEAWAT V.4 software. $\mathrm{X}$ is the distance of the well from the coastline which is represented by a uniform vertical line, while $\mathrm{Z}$ is the thickness of the aquifer which is represented by a uniform horizontal layer. The red dot is the groundwater pumping point. The red line is the $1 \%$ isochlor concentration line with a concentration value of $500 \mathrm{mg} / \mathrm{l}$, the blue line is the $50 \%$ isochlor concentration line with a concentration value of 17,500 $\mathrm{mg} / \mathrm{l}$ and the black line is the $95 \%$ isochlor concentration line with a concentration value of $33,250 \mathrm{mg} / \mathrm{l}$. Each case will be modelled with a pumping distance of $3 / 4 \mathrm{Xt}$ and a pumping depth of $2 / 5 \mathrm{Z}$.

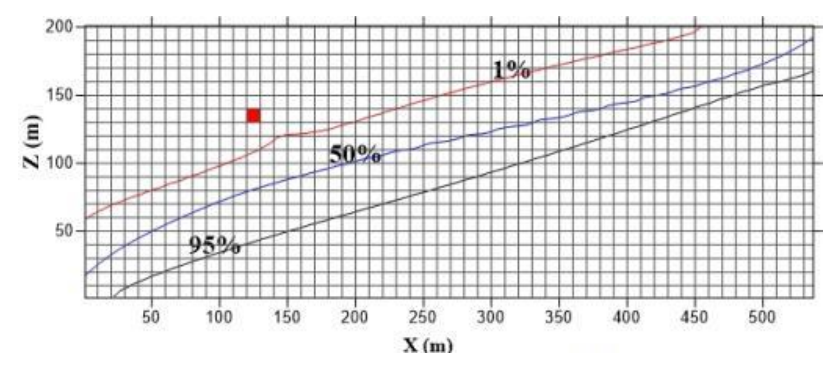

Figure3. Description of pumping modelling with SEAWAT V.4

\section{Results and Discussion}

\section{A. Distribution of Water Quality in Pumping Well}

From the results of measurements of shallow well samples conducted on the north coast of Makassar City using GPS Geo 7X, obtained the coordinates of the sampling points as in Table 2 . 
Table 2. Pumping well point coordinates

\begin{tabular}{cccc}
\hline \multirow{2}{*}{$\begin{array}{c}\text { Sample } \\
\text { point }\end{array}$} & \multicolumn{2}{c}{ Coordinates } & District \\
\cline { 2 - 3 } & $\mathbf{X}$ & $\mathbf{Y}$ & \\
\hline P1 & 767338 & 9433000 & Wajo \\
\hline P2 & 767730 & 9432893 & Wajo \\
\hline P3 & 767868 & 9432722 & Wajo \\
\hline P4 & 768517 & 9434178 & Ujung Tanah \\
\hline P5 & 767679 & 9433984 & Ujung Tanah \\
\hline P6 & 768385 & 9434002 & Ujung Tanah \\
\hline P7 & 768239 & 9433630 & Ujung Tanah \\
\hline P8 & 768210 & 9434289 & Ujung Tanah \\
\hline P9 & 767377 & 9433580 & Wajo \\
\hline P10 & 767424 & 9432733 & Wajo \\
\hline
\end{tabular}

Primary data obtained from the results of measurements of shallow well samples conducted on the north coast of Makassar City using GPS Geo 7X, water level and roller meters can be seen in Table 3.

Table 3. Measurement results at pumping well sample points.

\begin{tabular}{|c|c|c|c|}
\hline \multirow{2}{*}{$\begin{array}{c}\text { Sample } \\
\text { points }\end{array}$} & $\begin{array}{l}\text { Groundwater } \\
\text { level }\end{array}$ & $\begin{array}{c}\text { Soil } \\
\text { elevation }\end{array}$ & Distance \\
\hline & $\mathbf{m}$ & $\mathbf{m}$ & $\mathbf{m}$ \\
\hline P1 & 0,79 & 3,46 & 494,04 \\
\hline $\mathrm{P} 2$ & 1,09 & 4,63 & 900,34 \\
\hline P3 & 0,81 & 3,53 & 937,69 \\
\hline $\mathrm{P} 4$ & 1,08 & 3,54 & 194,33 \\
\hline P5 & 1,37 & 3,49 & 460,67 \\
\hline P6 & 1,22 & 3,02 & 537,15 \\
\hline P7 & 1,14 & 6,25 & 868,56 \\
\hline P8 & 1,27 & 3,32 & 209,18 \\
\hline P9 & 1,21 & 7,32 & 405,79 \\
\hline P10 & 1,11 & 4,07 & 519,66 \\
\hline
\end{tabular}

Salinity testing for well water samples was conducted at the Environmental Laboratory of South Sulawesi Province with parameters in the form of chloride content found in water samples. Laboratory test results obtained can be seen in Table 4.
Table 4. Laboratory test results of pumping well water samples

\begin{tabular}{cccc}
\hline $\begin{array}{c}\text { Sample } \\
\text { point }\end{array}$ & \multicolumn{2}{c}{ Coordinate } & Salinity \\
\cline { 2 - 4 } & $\mathbf{X}$ & $\mathbf{Y}$ & $\mathbf{m g} / \mathbf{l}$ \\
\hline P1 & 767338 & 9433000 & 36,9 \\
\hline P2 & 767730 & 9432893 & 22,0 \\
\hline P3 & 767868 & 9432722 & 69,0 \\
\hline P4 & 768517 & 9434178 & 23,5 \\
\hline P5 & 767679 & 9433984 & 12,7 \\
\hline P6 & 768385 & 9434002 & 52,8 \\
\hline P7 & 768239 & 9433630 & 5,4 \\
\hline P8 & 768210 & 9434289 & 53,3 \\
\hline P9 & 767377 & 9433580 & 57,2 \\
\hline P10 & 767424 & 9432733 & 35,2 \\
\hline
\end{tabular}

Based on the salinity test results from 10 well water samples on the north coast of Makassar City, the salinity values obtained were classified based on the amount of salinity in the water according to [15]. All well water samples included in the category of non-saline (freshwater) with a salinity value $<500 \mathrm{mg} / \mathrm{l}$. Freshwater is water that does not taste and does not contain much salt or other mineral solutions, so it is safe to be used as drinking water for humans.

Based on the Groundwater Utilization Monitoring Activity Report by the Makassar City Environment Office in 2018, observations of seawater infiltration based on alkalinity concentration ( $\mathrm{R}$ values) are estimated to occur around Ujung Pandang District, Biringkanaya District, Rappocini District, Tallo District and Panakkukang District. So that the Ujung Tanah and Wajo Districts are expected to have not experienced seawater infiltration so that the well water in both districts is still classified as freshwater. Judging from the chemical parameters namely Hardness, Chloride, Nitrite, BOD, DO, Salinity and $\mathrm{pH}$ that exceed the quality standards can be seen in the area around the District of Ujung Based on chemical parameters, Ujung Tanah District and Wajo District have not exceeded the quality standard so they are still classified as safe for use as 
drinking water. Although at present, the condition of well water in the north coastal area of Makassar City is still in fresh condition so it is safe for consumption but groundwater pollution due to seawater intrusion in the area is very likely to occur because of the location of shallow wells of communities that are very close to the sea, precisely to the north of Makassar City which is directly adjacent to the sea. If groundwater extraction is carried out irregularly with large discharges at certain depths and locations that are less strategic, it can trigger up-coning so that well water becomes salty and no longer suitable for consumption as drinking water. The results of measurements in the field and the results of water salinity laboratory tests in the Environmental Laboratory unit of South Sulawesi Province are shown in Figure 4.

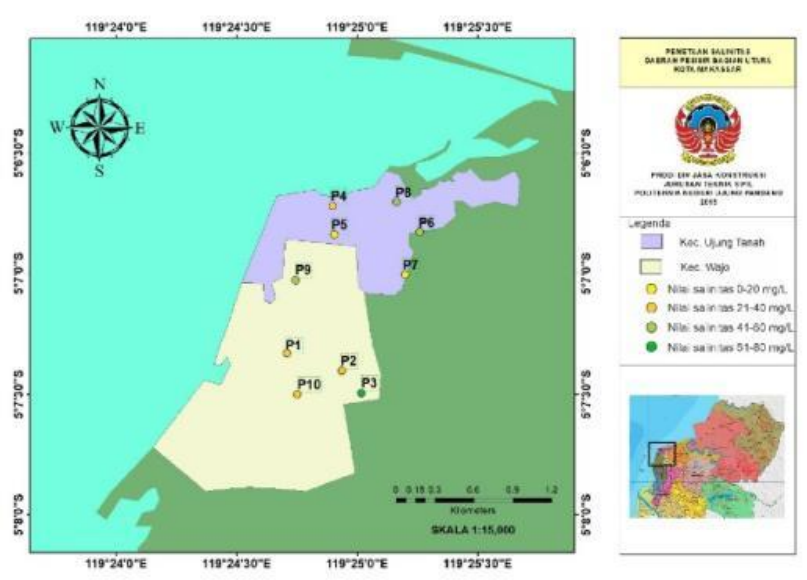

Figure 4. Map of salinity distribution in the north coastal region of Makassar City.

\section{B. Groundwater Pumping Settings Numerical Model}

Groundwater pumping modelling in the north coastal area of Makassar City was carried out using SEAWAT V.4 application by adjusting the position, depth and discharge of the pumping. Modelling is presented in 2 dimensions with an estimated time of the next 100 years. The sample points that are modelled are P3, P5, P6 and P10. Aquifer conceptualization of the four research location points used in numerical models and modelled in 2 dimensions and cross-sections perpendicular to the coast. Each point is modelled in 1 pumping position with a certain pumping point and discharge depth until it reaches a maximum flow that is safe to pump before reaching up-coning.

\section{a. $\quad$ Case P3}

$\mathrm{Xt}=334 \mathrm{~m}$

$3 / 4 \mathrm{Xt}=250,5 \mathrm{~m}$

Pumping distance for Case P3 is $250,5 \mathrm{~m}$ from the coastline

$\mathrm{Z} \quad=80 \mathrm{~m}$

$2 / 5 \mathrm{Z}=32 \mathrm{~m}$

Pumping depth for Case P3 is $32 \mathrm{~m}$.

Figure 5 is a steady-state condition before pumping. This case is modeled in two dimensions, and the crosssection is perpendicular to the beach. The domain model is uniformly discredited in carrying out "steady-state" simulations. For aquifers at Case P3 use 469 vertical columns with a width of $2 \mathrm{~m}$ and 42 horizontal layers with a thickness of $2 \mathrm{~m}$.

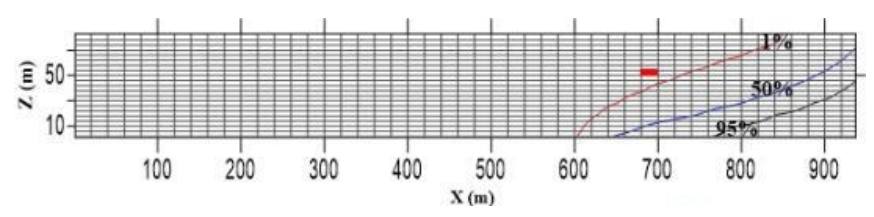

Figure5. P3 condition before pumping

Table5. Modelling results for Case P3.

\begin{tabular}{|c|c|c|c|c|c|c|}
\hline \multirow{2}{*}{ No } & \multicolumn{2}{|c|}{ Flow rate } & \multirow{2}{*}{$\frac{\text { Distance (Xt) }}{\mathrm{m}}$} & \multirow{2}{*}{$\begin{array}{c}\text { Depth } \\
\mathbf{m}\end{array}$} & \multirow{2}{*}{$\begin{array}{l}\text { Period } \\
\text { (years) }\end{array}$} & \multirow{2}{*}{ Indicator } \\
\hline & $\mathrm{m}^{3 / 4}$ & & & & & \\
\hline 1 & Q10\% & 0.15 & 250,5 & 32 & - & $\begin{array}{l}\text { Up-coning has } \\
\text { not happened, } \\
\text { wells have not } \\
\text { contaminated }\end{array}$ \\
\hline 2 & Q20\% & 0,30 & 250,5 & 32 & 10 & $\begin{array}{l}\text { Up-coning is } \\
\text { started, wells } \\
\text { have not } \\
\text { contaminated }\end{array}$ \\
\hline 3 & Q30\% & 0,45 & 250,5 & 32 & 10 & $\begin{array}{l}\text { Up-coning is } \\
\text { started, wells } \\
\text { have not } \\
\text { contaminated }\end{array}$ \\
\hline 4 & Q40\% & 0,60 & 250,5 & 32 & 16 & $\begin{array}{l}\text { Up-coning has } \\
\text { occurred, Wells } \\
\text { have been } \\
\text { contaminated }\end{array}$ \\
\hline
\end{tabular}

Thus from Table 5, for the position of P3 in the pumping position of $250.5 \mathrm{~m}$ from the coastline with a pumping depth of $32 \mathrm{~m}$, the maximum safe discharge for use in pumping is $20 \%$ of the total $\mathrm{Q}\left(0.30 \mathrm{~m}^{3} /\right.$ day $)$. 


\section{b. Case P5}

$\mathrm{Xt}=462 \mathrm{~m}$

$3 / 4 \mathrm{Xt}=346,5 \mathrm{~m}$

Pumping distance for Case P5 is 346,5 m from the coast line

$\mathrm{Z} \quad=200 \mathrm{~m}$

$2 / 5 \mathrm{Z}=80 \mathrm{~m}$

Pumping depth for Case P5 is $80 \mathrm{~m}$.

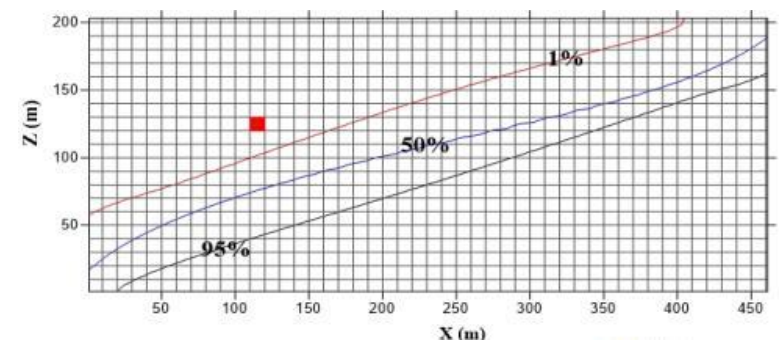

Figure 6. P5 Condition before pumping

Figure 6 shows a steady-state condition before pumping. This case is modeled in two dimensions and the cross-section is perpendicular to the beach. The domain model is uniformly discretized in carrying out "steady-state" simulations. For aquifers in the case of P6 used 231 vertical columns with a width of $2 \mathrm{~m}$ and 102 horizontal layers with a thickness of $2 \mathrm{~m}$.

Table 6. Modelling results For Case P5.

\begin{tabular}{|c|c|c|c|c|c|c|}
\hline \multirow{2}{*}{ No } & \multicolumn{2}{|c|}{ Flow rate } & \multirow{2}{*}{$\frac{\text { Distance (Xt) }}{\mathrm{m}}$} & \multirow{2}{*}{$\frac{\text { Depth }}{\mathrm{m}}$} & \multirow{2}{*}{$\begin{array}{l}\text { Period } \\
\text { (years) }\end{array}$} & \multirow{2}{*}{ Indicator } \\
\hline & $\mathrm{m}^{3 / d}$ & & & & & \\
\hline 1 & Q40\% & 1,32 & 346.5 & 80 & 10 & $\begin{array}{l}\text { Up-coning has } \\
\text { started, wells } \\
\text { have not } \\
\text { contaminated }\end{array}$ \\
\hline 2 & Q60\% & 1,99 & 346.5 & 80 & 1 & $\begin{array}{l}\text { Up-coning has } \\
\text { started, wells } \\
\text { have not } \\
\text { contaminated }\end{array}$ \\
\hline 3 & Q80\% & 2,65 & 346.5 & 80 & 1 & $\begin{array}{l}\text { Up-coning has } \\
\text { started, wells } \\
\text { have not } \\
\text { contaminated }\end{array}$ \\
\hline 4 & Q100\% & 3,31 & 346.5 & 80 & 23 & $\begin{array}{l}\text { Up-coning has } \\
\text { occurred, wells } \\
\text { have been } \\
\text { contaminated }\end{array}$ \\
\hline
\end{tabular}

Thus from Table 6, for the position of the P5 case at the pumping position $346.5 \mathrm{~m}$ from the shoreline with a pumping depth of $80 \mathrm{~m}$, the maximum safe discharge for use in pumping is $40 \%$ of $Q$ total $\left(1.32 \mathrm{~m}^{3} /\right.$ day $)$.

\section{c. Case P6}

$\mathrm{Xt}=528 \mathrm{~m}$

$3 / 4 \mathrm{Xt}=403,5 \mathrm{~m}$

Pumping distance for Case P6 is 403,5 m from the coast line

$$
\mathrm{Z} \quad=200 \mathrm{~m}
$$$$
2 / 5 \mathrm{Z}=80 \mathrm{~m}
$$

Pumping depth for CaseP6 is $80 \mathrm{~m}$.

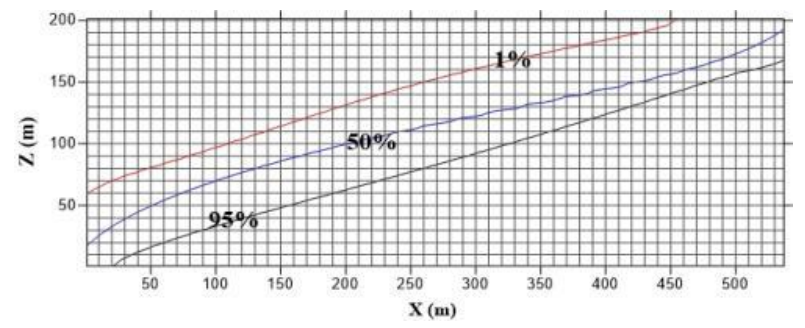

Figure 7. P6 condition before pumping

Figure 7 shows a steady-state condition before pumping. This case is modelled in two dimensions and the cross-section is perpendicular to the beach. The domain model is uniformly discretized in carrying out "steady-state" simulations. For aquifers in the case of P6 using 269 vertical columns with a width of $2 \mathrm{~m}$ and 102 horizontal layers with a thickness of $2 \mathrm{~m}$.

Table 7. Modelling Results for Case P6

\begin{tabular}{|c|c|c|c|c|c|c|}
\hline \multirow{2}{*}{ No } & \multicolumn{2}{|c|}{ Flow rate } & \multirow{2}{*}{$\frac{\text { Distance (Xt) }}{\mathrm{m}}$} & \multirow{2}{*}{$\frac{\text { Depth }}{\mathrm{m}}$} & \multirow{2}{*}{$\begin{array}{l}\text { Period } \\
\text { (years) }\end{array}$} & \multirow{2}{*}{ Indicator } \\
\hline & $\mathrm{m}^{3 / \mathrm{d}}$ & & & & & \\
\hline 1 & Q20\% & 0,52 & 403.5 & 80 & 10 & $\begin{array}{l}\text { Up-coning has } \\
\text { started, wells } \\
\text { have not } \\
\text { contaminated }\end{array}$ \\
\hline 2 & Q40\% & 1,03 & 403.5 & 80 & 1 & $\begin{array}{l}\text { Up-coning has } \\
\text { started, wells } \\
\text { have not } \\
\text { contaminated }\end{array}$ \\
\hline 3 & Q60\% & 2,07 & 403.5 & 80 & 1 & $\begin{array}{l}\text { Up-coning has } \\
\text { started, wells } \\
\text { have not } \\
\text { contaminated }\end{array}$ \\
\hline 4 & Q100\% & 2,58 & 403.5 & 80 & 2 & $\begin{array}{l}\text { Up-coning has } \\
\text { occurred, wells } \\
\text { have been } \\
\text { contaminated }\end{array}$ \\
\hline
\end{tabular}

Thus from Table 7, for the position of the P6 case at the pumping position of $403.5 \mathrm{~m}$ from the coastline with a pumping depth of $80 \mathrm{~m}$, the maximum safe discharge 
for use in pumping to avoid contamination under sustainable conditions is $0.52 \mathrm{~m}^{3} /$ day.

\section{d. Case P10}

$\mathrm{Xt}=182 \mathrm{~m}$

$3 / 4 \mathrm{Xt}=136,5 \mathrm{~m}$

Pumping distance for Case P10 is $136,5 \mathrm{~m}$ from the coast line

$\mathrm{Z}=80 \mathrm{~m}$

$2 / 5 \mathrm{Z}=32 \mathrm{~m}$

Pumping depth for Case P10 is $32 \mathrm{~m}$.

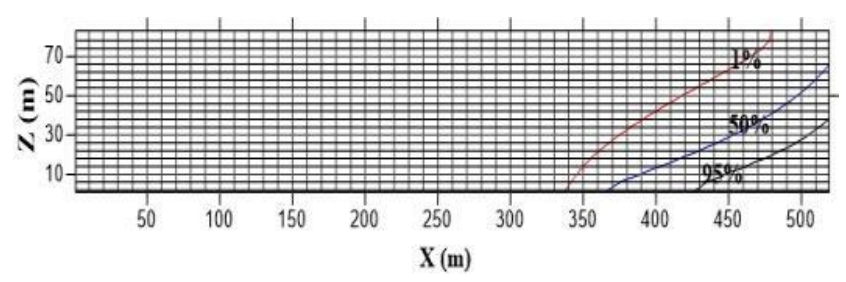

Figure 8. P10 condition before pumping

Figure 8 shows the steady-state conditions before pumping. This case is modelled in two dimensions and the cross-section is perpendicular to the beach. The domain model is uniformly discretized in carrying out "steady-state" simulations. For aquifers in Case P6 use 260 vertical columns with a width of $2 \mathrm{~m}$ and 42 horizontal layers with a thickness of $2 \mathrm{~m}$.

Table 8. Modelling results for Case P10

\begin{tabular}{|c|c|c|c|c|c|c|}
\hline \multirow{2}{*}{ No } & \multicolumn{2}{|c|}{ Flow rate } & \multirow{2}{*}{$\frac{\text { Distance (Xt) }}{\mathrm{m}}$} & \multirow{2}{*}{$\frac{\text { Depth }}{\mathrm{m}}$} & \multirow{2}{*}{$\begin{array}{l}\text { Period } \\
\text { (years) }\end{array}$} & \multirow{2}{*}{ Indicator } \\
\hline & $\mathrm{m}^{3 / \mathrm{c}}$ & & & & & \\
\hline 1 & Q20\% & 0,63 & 136.5 & 32 & - & $\begin{array}{c}\text { Up-coning has } \\
\text { started, wells } \\
\text { have not } \\
\text { contaminated }\end{array}$ \\
\hline 2 & Q40\% & 1,25 & 136.5 & 32 & 10 & $\begin{array}{l}\text { Up-coning has } \\
\text { started, wells } \\
\text { have not } \\
\text { contaminated }\end{array}$ \\
\hline 3 & Q60\% & 1,88 & 136.5 & 32 & 5 & $\begin{array}{l}\text { Up-coning has } \\
\text { happened, wells } \\
\text { have been } \\
\text { contaminated }\end{array}$ \\
\hline
\end{tabular}

Thus from Table 8, for the position of the P10 case at the pumping position of $136.5 \mathrm{~m}$ from the coastline with a pumping depth of $32 \mathrm{~m}$, the maximum safe discharge for use in pumping to avoid contamination under sustainable conditions is $0.63 \mathrm{~m}^{3} /$ day. The maximum pumping rates that can be done for each observation well is shown in Table 9.
Table 9. Maximum pumping rates obtained from the numerical model for all cases.

\begin{tabular}{lcc}
\hline \multirow{2}{*}{ No } & Case & Max Flowrate \\
\cline { 3 - 3 } & & $\mathbf{m}^{3 / \mathbf{d a y}}$ \\
\hline 1 & P3 & 0,30 \\
\hline 2 & P5 & 1,32 \\
\hline 3 & P6 & 0,52 \\
\hline 4 & P10 & 0.63 \\
\hline
\end{tabular}

Based on the simulation results of groundwater pumping with SEAWAT V.4, it can be seen that the length of seawater intrusion that occurred in steady-state conditions in the P3 case for $1 \%$ isochlor concentration is $324 \mathrm{~m}, 50 \%$ is $294 \mathrm{~m}$ and $95 \%$ is $174 \mathrm{~m}$. In the case of $\mathrm{P} 5$ the concentration of $1 \%$ isochlor is $462 \mathrm{~m}$. In the case of P6 for a concentration of $1 \%$ it was $538 \mathrm{~m}$. Whereas in the P10 case for $1 \%$ isochlor concentration was 182 $\mathrm{m}, 50 \%$ was $154 \mathrm{~m}$ and $95 \%$ was $94 \mathrm{~m}$.

To get a sustainable condition, it was found that at position P3 (distance of $250.5 \mathrm{~m}$ from the coastline and pumping depth of $32 \mathrm{~m}$ ) the maximum discharge that can be used to prevent contamination is Q20\% (0.30 $\mathrm{m}^{3} /$ day). For position P5 (a distance of $346.5 \mathrm{~m}$ from the coastline and pumping depth of $80 \mathrm{~m}$ ) the maximum discharge that can be used is Q40\% (1.32 $\mathrm{m}^{3} /$ day). For position P6 (a distance of $403.5 \mathrm{~m}$ from the coastline and pumping depth of $80 \mathrm{~m}$ ) the maximum discharge that can be used is Q40\% (1.03 $\mathrm{m}^{3} /$ day). As for the position of P10 (distance $136.5 \mathrm{~m}$ from the coastline and pumping depth $32 \mathrm{~m}$ ), the maximum discharge that can be used is Q20\% (0.63 $\mathrm{m}^{3} /$ day).

In the case of P3 with a Q20\% discharge $(0.3$ $\mathrm{m}^{3} /$ day), if pumping is carried out on an ongoing basis, then up-coning will occur in the 10th year. For the case of $\mathrm{P} 5$ with a Q40\% discharge $\left(1.32 \mathrm{~m}^{3} /\right.$ day) there will be an up-coning in the 10th year. For the P6 case with a Q20\% discharge $\left(0.52 \mathrm{~m}^{3} /\right.$ day $)$ there will be an upconing in the 10th year. Whereas in the case of P10 with a Q40\% discharge $\left(1.25 \mathrm{~m}^{3} /\right.$ day $)$ there will be an upconing in the 10th year.

In the case of P3 with a Q40\% discharge $(0.60$ $\mathrm{m}^{3} /$ day), if pumping is carried out on an ongoing basis, then contamination will occur in the 16th year. For the case of P5 with Q100\% discharge (3.31 $\mathrm{m}^{3} /$ day), 
contamination will occur in the 23rd year. For P6 cases with Q100\% discharge $\left(2.58 \mathrm{~m}^{3} /\right.$ day $)$ contamination will occur in the 2 nd year. Whereas in the case of P10 with a Q60\% discharge $\left(1.88 \mathrm{~m}^{3} /\right.$ day $)$ contamination will occur in the 5 th year.

\section{Conclusion}

From the results of research in the north coastal area of Makassar City, it was concluded that based on the salinity test in the laboratory, the average salinity value in the ten samples tested was $36.8 \mathrm{mg} / 1$. The results showed that all well water samples located in Ujung Tanah and Wajo Districts were included in the nonsaline (freshwater) classification. Based on groundwater pumping simulation using SEAWAT V.4, to obtain a sustainable condition, it was found that at position P3 (distance $250.5 \mathrm{~m}$ from the coastline and pumping depth $32 \mathrm{~m})$ the maximum discharge that can be used to prevent up-coning is Q20\% $\left(0.30 \mathrm{~m}^{3} /\right.$ day $)$. For position P5 (a distance of $346.5 \mathrm{~m}$ from the coastline and pumping depth of $80 \mathrm{~m}$ ) the maximum discharge that can be used is Q40\% (1.32 $\mathrm{m}^{3} /$ day). For position P6 (a distance of $403.5 \mathrm{~m}$ from the coastline and pumping depth of $80 \mathrm{~m}$ ) the maximum discharge that can be used is $\mathrm{Q} 40 \%\left(1.03 \mathrm{~m}^{3} /\right.$ day). As for the position of $\mathrm{P} 10$ (distance $136.5 \mathrm{~m}$ from the coastline and pumping depth $32 \mathrm{~m}$ ), the maximum discharge that can be used is Q20\% $\left(0.63 \mathrm{~m}^{3} /\right.$ day $)$.

\section{Acknowledgement}

The authors wish to thank the head of Civil Engineering Department of Politeknik Negeri Ujung Pandang for the support.

\section{References}

[1] Russo, T. A., \& Lall, U. Depletion and response of deep groundwater to climate-induced pumping variability. Nature Geoscience, 10(2), 105-108. 2017.

[2] Freeze, R. Allan and Cherry, John A. Groundwater. Prentice Gll, Inc.,Englewood Cliffs. New Jersey. 1979.

[3] Badaruddin, S., Werner, A. D., \& Morgan, L. K. Characteristics of active seawater intrusion. Journal of Hydrology, 551, 632-647. 2017.
[4] Badaruddin, S, Akhmad Azis, and Indra Mutiara. Analytical and Numerical Model Application on Seawater Intrusion Prediction in Jeneponto Regency, Politeknik Negeri Ujung Pandang. 2018.

[5] Jakovovic, D., Post, V. E., Werner, A. D., Männicke, O., Hutson, J. L., \& Simmons, C. T. Tracer adsorption in sand-tank experiments of saltwater up-coning. Journal of Hydrology, 414, 476-481. 2012.

[6] Werner, A. D., Jakovovic, D., \& Simmons, C. T. Experimental observations of saltwater up-coning. Journal of Hydrology, 373(1-2), 230-241. 2009.

[7] Dagan, G., \& Bear, J. Solving the problem of local interface upconing in a coastal aquifer by the method of small perturbations. Journal of hydraulic research, 6(1), 15-44. 1968.

[8] Diersch, H. J., Prochnow, D., \& Thiele, M. Finite-element analysis of dispersion-affected saltwater upconing below a pumping well. Applied Mathematical Modelling, 8(5), 305312. 1984.

[9] Holzbecher, E. O. Saltwater Upconing. In Modeling DensityDriven Flow in Porous Media (pp. 213-225). Springer, Berlin, Heidelberg. 1998.

[10] Badaruddin, S., Werner, A. D., \& Morgan, L. K. Water table salinization due to seawater intrusion. Water Resources Research, 51(10), 8397-8408. 2015.

[11] Darwis. Fundamental of Soil Mechanics, Yogyakarta : Pena Indis. 2018.

[12] Fetter. C.W. Applied hydrogeology. New Jersey. 1998.

[13] Damayanti, Annisa Dwi. Study of Shallow Groundwater Salinity in the Northern Coastal Area of Makassar, Civil Engineering Hasanuddin University. 2015.

[14] Langevin, C. D., Thorne Jr, D. T., Dausman, A. M., Sukop, M. C., \& Guo, W. SEAWAT version 4: a computer program for simulation of multi-species solute and heat transport (No. 6A22). Geological Survey (US). 2008.

[15] FAO, 1988. Classification of Saline Waters. http://www/fao/org/docrep/t0667e/t0667e05.htm.Diakses pada tanggal 20 Desember 2018. 